\title{
The effect of ultrasonography guided intra-articular corticosteroid injections in advanced knee osteoarthritis
}

\author{
Illeri evre diz osteoartritinde ultrasonografi eşliğinde intraartiküler uygulanan \\ kortikosteroidlerin etkisi
}

\author{
Figen Koçyiğit* Ersin Kuyucu**, Ali Koçyiğit ${ }^{* * *}$ \\ *Pamukkale Üniversitesi, Fizik Tedavi ve Rehabilitasyon Yüksekokulu, Denizli \\ ** Denizli Devlet Hastanesi, Ortopedi ve Travmatoloji Kliniği, Denizli \\ *** Pamukkale Üniversitesi Tıp Fakültesi, Radyoloji AD, Denizli
}

\begin{abstract}
Purpose: The aim of the study is to evaluate the effect of ultrasonography-guided intra-articular corticosteroid injection on pain, functional status and quality of life in patients with advanced knee osteoarthrit.

Materials and methods: 50 knees of 26 patients who were diagnosed as grade 4 knee osteoarthritis according to Kellgren - Lawrence classification system were treated with ultrasonography-guided intra-articular injection of $40 \mathrm{mg}$ triamcinolone acetonide. Perceived pain, weekly analgesic consumption, findings of physical examination, knee pain threshold, functional status and quality of life were evaluated before and four weeks after the injection. Western - Ontario and McMaster Universities' (WOMAC) osteoarthritis index was used to assess functional status, and Nottingham Health Profile (NHP) was used to evaluate the quality of life.

Results: Mean age of the patients in the study was $65 \pm 7.5$ years and mean symptom duration was $74.7 \pm 32.5$ months. Visual analog scale for pain decreased from 85.3. $\pm 14.1 \mathrm{~mm}$ to $59,6 \pm 21.1 \mathrm{~mm}(p=0.003)$ and mean analgesic consumption decreased from $8 \pm 3$ to $3 \pm 2(p=0.000)$. Total WOMAC score $(p=0.000)$ and scores of 4 NHP subdivisions (pain $(p=0.000)$; physical mobility $(p=0.003)$, social isolation $(p=0.012)$; emotional reactions $(p=0.016)$ decreased significantly 4 weeks after the injection.

Conclusion: Injection under ultrasonography guidance may improve the beneficial effects of corticosteroids in advanced knee osteoarthritis.
\end{abstract}

Pam Med J 2015;8(3):193-198

Key words: intraarticular injection, corticosteroids, osteoarthritis; interventional ultrasonography.

\section{Özet}

Amaç: Bu çalışmanın amacı ileri evre diz osteorartriti olan hastalarda, ultrasonografi eşliğinde yapılan intraartiküler kortikosteroid enjeksiyonlarının, ağrı, fonksiyonel durum ve hayat kalitesi üzerine olan etkilerinin araştırılmasıdır.

Gereç ve yöntem: Kellgren -Lawrence sınıflandırma sistemine göre evre 4 diz osteoartriti olan 26 hastanın 50 dizine ultrasonografi eşliğinde intraartiküler $40 \mathrm{mg}$ triamsinolon asetonid uygulandı. Hastanın algıladığı ağrı, haftalık analjezik ilaç ihtiyacı, fizik muayene bulguları, diz ağrı eşiği, fonksiyonel durum ve yaşam kalitesi enjeksiyondan önce ve 4 hafta sonar değerlendirildi. Fonksiyonel durumun değerlendirilmesi için Western Ontario ve McMaster Üniversiteleri (WOMAC) osteoartrit indeksi, yaşam kalitesinin değerlendirilmesi için Nottingham Sağıık Profili (NHP) kullanıldı.

Bulgular: Çalışmaya dahil edilen hastaların ortalama yaşı $65 \pm 7.5$ yıl, belirti süresi $74.7 \pm 32.5$ aydı. Ağrı için vizüel analog skala $85,3 \pm 14.1 \mathrm{~mm}$ den $59,6 \pm 21,1 \mathrm{~mm}$ 'ye $(p=0.003)$; haftalık analjezik tüketimi $8 \pm 3$ tabletten $3 \pm 2$ tablete $(p=0.000)$ geriledi. Toplam WOMAC skoru $(p=0.000)$ ve NHP ağrı $(p=0.000)$, fiziksel aktivite $(p=0.003)$, sosyal izolasyon $(p=0.012)$, emosyonel reaksiyonlar $(p=0.016)$ skorları enjeksiyondan 4 hafta sonra istatistiksel olarak anlamlı şekilde azaldı.

Sonuç: İleri evre diz osteartritinde enjeksiyonun ultrasonografi eşliğinde yapılması kortikosteroidlerin yararlarını arttırabilir.

Pam Tıp Derg 2015;8(3):193-198

Anahtar sözcükler: İntraartiküler enjeksiyonlar, kortikosteroidler, osteoartrit; girişimsel ultrasonografi.

Figen Koçyiğit

Yazışma Adresi:Pamukkale Üniversitesi, Fizik Tedavi ve Rehabilitasyon Yüksekokulu, Denizli

e-mail: figen7876@yahoo.com

Gönderilme tarihi: 23.02.2015 Kabul tarihi: 16.03.2015 


\section{Introduction}

Knee osteoarthritis may affect functional capacity and quality of life as a result of pain, stiffness and decreased range of motion [1]. Pain management and continuation of daily life activities are important issues especially in patients with advanced knee osteoarthritis who are not suitable for surgery or do not accept surgical treatment.

Intra-articular (IA) corticosteroid injection is a treatment alternative for patients who do not respond to or cannot tolerate oral and parenteral systemic treatment [2]. American College of Rheumatology (ACR) reported IA corticosteroids as an appropriate treatment choice for patients who did not respond to preliminary treatment [3]. Knee pain is reported to decrease in the first 1-2 weeks after the injection in reviews evaluating the effects of IA corticosteroids in knee osteoarthritis. However, authors commented that the effect is not expected to last longer than 3-4 weeks [4, 5]. The targeting accuracy of IA injection is a critical factor for the duration of analgesic effect. Blinded IA injections without using a guide were reported to reach IA space in $64-87 \%$ of the administrations [6]. To the best of our knowledge, Ultrasonography (USG) guidance was not used in the previous studies about the effect of IA corticosteroid injection in advanced knee osteoarthritis.

The objective of our study is to evaluate the impact of USG guided IA corticosteroid injection on pain, quality of life, functional status and the analgesic need in patients with KellgrenLawrence grade 4 knee osteoarthritis.

\section{Materials and Methods}

\section{Patients and Clinical Evaluation}

Our study included 50 knees of 26 patients who were diagnosed as knee osteoarthritis according to ACR clinical and radiological diagnostic criteria and had grade 4 according to Kellgren-Lawrence radiological classification.

The exclusion criteria were presence of knee effusion, presence of inflammatory joint disease, history of IA knee injection in last 6 months and presence of contraindication for corticosteroid use. Two patients had total knee arthroplasty in one lower extremity and these two knees were not involved in the study. We questioned and recorded the demographic parameters, symptom duration, comorbidities, pain severity on $100 \mathrm{~mm}$ visual analog scale, analgesic need for one week of the recruited patients. We measured active range of motion of the knee. We evaluated the presence of knee joint medial and lateral tenderness, and inflammatory findings. We measured pain threshold at medial joint space with pressure algometer (Wagner Pain Test ${ }^{\mathrm{TM}}$ Model FPK 40 Algometer, Wagner Instruments, Greenwich, CT, USA). We applied Western -Ontario and McMaster Universities'(WOMAC) osteoarthritis index and Nottingham Health Profile (NHP) to evaluate functional status and quality of life.

WOMAC osteoarthritis index was developed in 1982 to assess pain, stiffness, and physical function in patients with hip and / or knee osteoarthritis. It is divided in three subscales (pain, stiffness, and physical function) and consists of 24 items evaluated by Likert scale. Validity and reliability of the Turkish version was documented in 2005 [7].

NHP is a self administered questionnaire that is used to determine and quantify perceived health problems. It is divided in 6 subscales (sleep, mobility, energy, pain, emotional reactions, social isolation) and consists of 38 items [8]. Validity and reliability of the Turkish version was documented in 2000 [9].

All of the participants gave written and oral informed consent. Patients were advised to use their analgesic when they experience pain that did not resolve with rest. The analgesic preferred by the patient was paracetamol in 16 patients, diclofenac sodium in 4 patients, ibuprofen in 4 patients and naproxen in 2 patients. We gave an analgesic diary to participants and requested to record their analgesic consumption. We did not change exercise receipt of the patients who do regular training. New exercise schedule was not given to patients who do not do regular exercise. We invited the patients to follow-up visits four weeks after the injection, and clinical and functional evaluations were repeated. Clinical evaluations of the patients were applied by the same investigator. Probable side effects of corticosteroid use such as injection site depigmentation, local atrophy, increase in blood pressure and blood glucose levels were questioned and assessed.

\section{USG guided knee injection}

An experienced invasive radiologist (AK) injected $40 \mathrm{mg}$ triamcinolone acetonide (TA) intra-articularly via medial approach under USG (Aplio XG, Toshiba Medicals, Tokyo, Japan) guidance after the clinical evaluation. Patient was laid in the supine position with the knee in full extension during the procedure. The 
7.5-12 MHz linear array probe was prepared and clothed according to standard sterility conditions. Probe was placed slightly oblique to medial patellar margin and $38 \mathrm{~mm} 22$ gauge needle was placed 45 degrees obliquely to the long axis of USG probe (Figure 1). Needle was inserted towards patellofemoral recess to reach intra-articular space (Figure 2). When needle tip is visualized in the IA space, a test injection of TA $(0.1 \mathrm{ml})$ was performed to check that the tip of the needle is in the correct position. When the injected fluid is seen in the articular space as hyperechoic bubbles, the rest of TA was infused slowly into the IA space (Figure 3). The radiologist terminated the procedure after the diffusion of drug in the articular space was observed on USG. The radiologist paid attention in order not to harm patellar and femoral cartilage during the procedure.

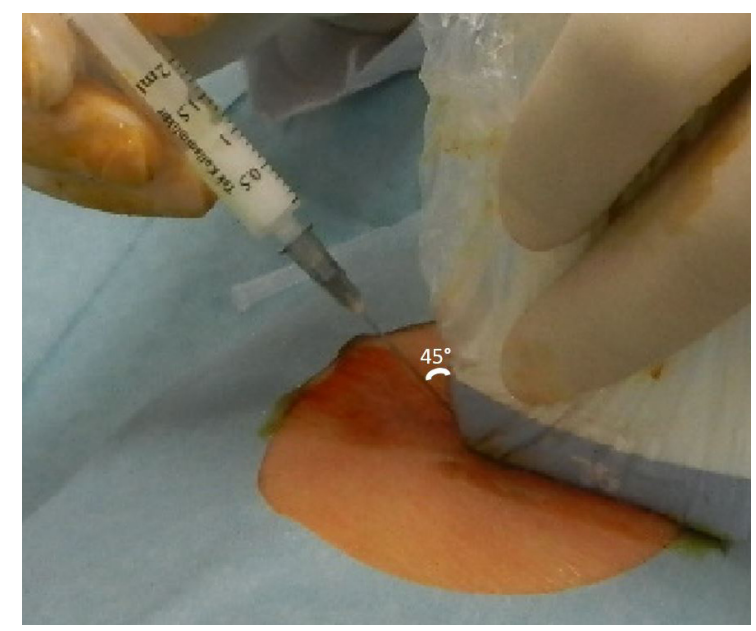

Figure 1. The probe and needle position for medial approach. The $45^{\circ}$ angle between the probe and needle is also showed on the figure.

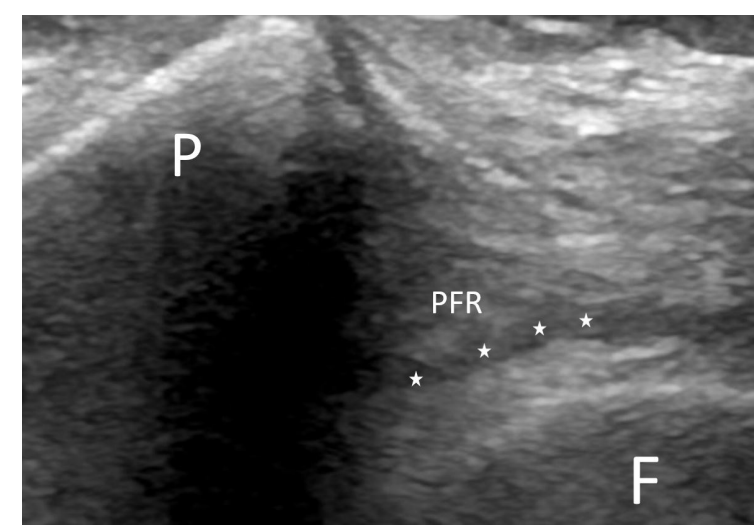

Figure 2. Demonstration of the sonographic image in medial approach. P; patella, PFR; patellofemoral recess, F; femur and the line marked with stars is articular space.

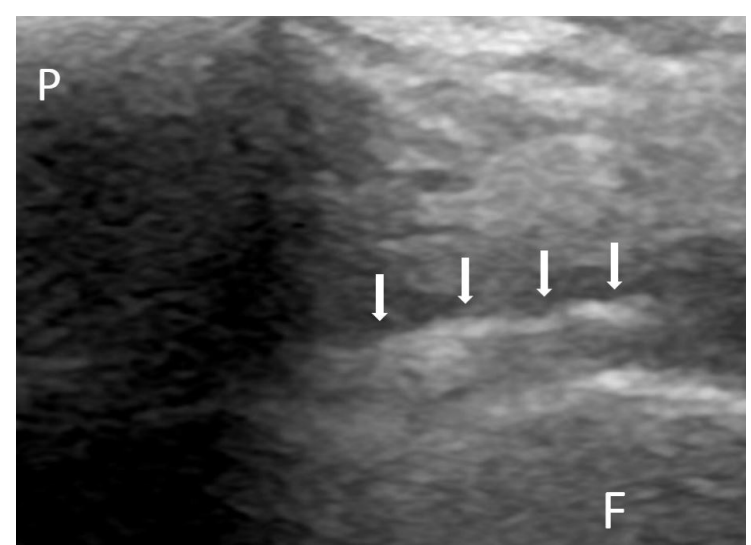

Figure 3. The air bubbles can be seen in the articular space after injection (White arrows). $\mathrm{P}$; patella, F; femur.

\section{Statistical Analysis}

Statistical analysis was performed with SPSS software, release 17.0 (SPSS Inc., an IBM Company, and Chicago, IL, USA). Standard descriptive statistics were used to summarize characteristics of the participants including means and standard deviations (SD) of all continuous variables and counts and percentages for the categorical variables. A-paired-sample T-test was used to compare objective outcomes. We defined two-sided statistical significance as $p<0.05$.

\section{Results}

The study included 50 involved knees of 26 patients (4 male, 22 female). Mean age of the participants was $65 \pm 7.5$ years (range, 57-79 years), and mean symptom duration was 74.7 \pm 32.5 months (range, 12-120 months). When we analyzed comorbidities of the patients; hypertension, and gastroesophageal reflux were present in 8 patients, diabetes mellitus and hyperlipidemia were present in 6 patients. Major depression, hypothyroidism, coronary heart disease were present in 4 patients (one patient may have more than 1 comorbidities). Three of the patients did not have any comorbidities.

The mean number of weekly consumed analgesics was $8 \pm 3$ tablets (range, 3-14 tablets). Knee joint medial tenderness was present in all of the 50 knees whereas knee joint; lateral tenderness was present in 42 of 50 knees. Mean pain pressure threshold was 5.11 $\pm 1.1 \mathrm{~kg}(3-7.5 \mathrm{~kg})$. Mean knee flexion was 120 $\pm 10.7^{\circ}$ (range, $95-135^{\circ}$ ), mean knee extension was $5.2 \pm 5.9^{\circ}\left(\right.$ range, $\left.0-15^{\circ}\right)$.

Mean VAS for pain before the injection was $85.3 \pm 14.1 \mathrm{~mm}$ (range, $47-98 \mathrm{~mm}$ ). Mean total 
WOMAC score was $76 \pm 14$ (range, 52-96). Mean NHP pain score was $94 \pm 9$ (range, 75$100)$, mean NHP physical activity score was 94 \pm 9 (range, 75-100). Patients applied for followup $33 \pm 8$ days (range, 24-51 days) after the injection.

Weekly analgesic consumption decreased to $3 \pm 2$ and mean VAS for pain decreased to $59.6 \pm 21.1 \mathrm{~mm}$. These changes in VAS for pain $(p=0.003)$ and the analgesic need $(p=0.000)$ after IA TA injection was significant statistically.
Regarding the physical examination findings there was no significant difference in the knee joint medial tenderness after the injection. However, lateral joint space tenderness was present in 26 of 50 patients, and this change was significant statistically $(p=0.039)$. Pressure pain threshold increased 4 weeks after the injection, but this change was not significant (Table 1).

Table 1. Changes in VAS pain threshold, analgesic consumption and physical examination findings after the treatment

\begin{tabular}{|c|c|c|c|}
\hline Parameter & Baseline & $4^{\text {th }}$-week follow-up & p-value \\
\hline Number of analgesic pill/week & $8 \pm 3$ & $3 \pm 3$ & 0.000 \\
\hline VAS*, for pain (mm) & $85.3 \pm 14.1(47-98)$ & $59.7 \pm 21.1(22-97)$ & 0.003 \\
\hline Pain threshold (kg) & $5.1 \pm 1.1(3-7.5)$ & $5.8 \pm 2.5(2.5-12)$ & 0.51 \\
\hline Knee joint lateral tenderness ${ }^{* *}$ & $42 / 50$ & $26 / 50$ & 0.039 \\
\hline Knee joint medial tenderness ${ }^{\star *}$ & $50 / 50$ & $46 / 50$ & 0.34 \\
\hline Knee flexion & $120 \pm 10.7^{\circ}\left(95-135^{\circ}\right)$ & $120 \pm 10.5^{\circ}\left(100-135^{\circ}\right)$ & 0.58 \\
\hline Knee extension & $5.2 \pm 5.9^{\circ}\left(0-15^{\circ}\right)$ & $5.6 \pm 5.9^{\circ}\left(0-15^{\circ}\right)$ & 0.54 \\
\hline
\end{tabular}

Total WOMAC score and subdivisions of WOMAC score (pain, stiffness, function) decreased significantly (Table 2). All subdivisions of NHP (energy, sleep, pain, emotional reactions, social isolation, and physical mobility) also decreased and all of the parameters except sleep and energy were significant statistically (Table 3 ). We did not encounter any complications and side effects of corticosteroid use in the study group.

Table 2. Changes in total WOMAC score and WOMAC subdivision scores after the treatment

\begin{tabular}{llll}
\hline \multicolumn{1}{c}{ Parameter } & \multicolumn{1}{c}{ Baseline } & $\mathbf{4}^{\text {th }}$-week follow-up & p-value \\
\hline WOMAC $^{*}$ pain score & $15.9 \pm 3.6$ & $10.3 \pm 4.1$ & 0.002 \\
WOMAC stiffness score & $5.8 \pm 2$ & $2.5 \pm 2.1$ & 0.006 \\
WOMAC physical function score & $55.2 \pm 10.7$ & $33.4 \pm 11.3$ & 0.000 \\
WOMAC total score & $76.8 \pm 14.2$ & $46.2 \pm 15.1$ & 0.000 \\
Total & $\mathbf{2 6}$ & $\mathbf{2 6}$ & \\
\hline
\end{tabular}

*:Western-Ontario and McMaster Universities' osteoarthritis index

Table 3. NHP subdivision scores before and 4 weeks after the treatment

\begin{tabular}{llll}
\hline \multicolumn{1}{c}{ Parameter } & \multicolumn{1}{c}{ Baseline } & \multicolumn{1}{c}{$\mathbf{4}^{\text {th }}$-week follow-up } & \multicolumn{1}{c}{ p-value } \\
\hline NHP* pain & $94.2 \pm 9.7$ & $57.1 \pm 20$ & 0.000 \\
NHP physical mobility & $70.2 \pm 19.5$ & $47.1 \pm 17.1$ & 0.003 \\
NHP energy & $66.6 \pm 30.5$ & $61.5 \pm 42.7$ & 0.587 \\
NHP sleep & $58.5 \pm 33.1$ & $41.5 \pm 38.7$ & 0.127 \\
NHP social isolation & $25 \pm 23.3$ & $7.7 \pm 10.1$ & 0.012 \\
NHP emotional reactions & $38.6 \pm 31.9$ & $15.4 \pm 20.5$ & 0.016 \\
Total & $\mathbf{2 6}$ & $\mathbf{2 6}$ & \\
*:Nottingham Health Profile & & & \\
\hline
\end{tabular}




\section{Discussion}

We investigated the effect of $40 \mathrm{mg}$ IA TA applied under USG guidance on pain, physical examination findings, analgesic consumption, functional status and quality of life in patients with advanced knee osteoarthritis in this study. Intra-articular TA improved pain, the analgesic need, physical activity and life quality of patients significantly after 4 weeks.

The effect of IA corticosteroids in knee osteoarthritis was documented in previous studies. However, duration of the effect is a matter of debate. Recent reviews reported a 1-2 week length of corticosteroid effect and predicted effect duration to be not more than 1-2 weeks [4, 5]. USG guided IA injection was shown to be effective after 4 weeks of this study in advanced knee osteoarthritis.

Probability of IA injections' reaching IA space is not $100 \%$ even when applied to the large and superficial joints by experienced rheumatologists. The probability decreases especially in obese patients with 'dry' knees without effusion [10]. The aim of IA injections is to provide high concentrations of corticosteroid in the synovial fluid, to reduce local inflammation while minimizing plasma concentrations and systemic side effects [11]. Therefore, these injections may be performed under fluoroscopy, direct roentgenogram and USG guidance.

Gaffney et al. [12] conducted a study to compare $20 \mathrm{mg}$ IA triamcinolone hexacetonide with placebo in knee osteoarthritis and reported significant improvement in pain with triamcinolone at the end of the first week. However, there was no difference between the groups at the end of 6 weeks. Dieppe et al. [13] conducted a similar study in 12 patients with symptom duration of 7.5 years. They compared $20 \mathrm{mg}$ IA triamcinolone hexacetonide with placebo and reported significant difference of VAS for pain only at the first week. Ravaud et al. [14] reported a 4-week duration of the effect of IA cortivazol when compared to joint lavage. VAS for pain, and subdivisions of both NHP and WOMAC scores for pain decreased significantly in our study. Furthermore, analgesic consumption decreased significantly. The number of weekly consumed analgesic pills decreased to $3 \pm 2$ from $8 \pm 2$. This decline in analgesic consumption is striking and significant when the geriatric nature and high number of comorbidities in our patient group are taken into account. The decrease in pain severity despite decrease in analgesic consumption is also significant. USG guidance was not used in any of the previous studies evaluating the effect of IA corticosteroids in knee osteoarthritis [4, 5]. Moreover, the applied dose was smaller than the ACR recommended dose [12-14]. Application of the recommended dose under USG guidance may have ameliorated the analgesic effect in this study even the patient group had advanced osteoarthritis.

The objective of treatment in advanced knee osteoarthritis is pain relief and independence in activities of daily living. Change in range of motion with treatment is not expected. We also did not observe difference in range of motion and knee joint medial tenderness. However, number of knees with knee joint, lateral tenderness decreased significantly in 4 weeks. Knee osteoarthritis affects the medial compartment more prominently. Despite being high grade according to radiological evaluation, the anti-inflammatory effect of TA may have alleviated the tenderness in lateral knee compartment. Widespread peri-articular tenderness in the knee makes lateral decubitus position difficult for the patient. Nevertheless, tenderness only in the medial joint space allows lateral decubitus position with a pillow between knees if necessary. Previous studies on IA corticosteroids for knee osteoarthritis did not evaluate the effect on joint tenderness. We believe that this is the first survey that allows to comment on joint tenderness after IA TA. We also observed increase in pain pressure threshold which supports analgesic effect of the IA TA. However, the change was not significant statistically.

The decrease in score of energy, sleep, pain, emotional reactions, social isolation, and physical mobility subdivisions of NHP implies an increase in the perceived quality of life. Both the total score and score of subdivisions of WOMAC osteoarthritis index decreased significantly. Jones and Doherty [15] reported no difference in quality of life assessed with Stanford Health Assessment Questionnaire (HAQ) at weeks 3 and 8 in patients having knee osteoarthritis and treated with IA $40 \mathrm{mg}$ methylprednisolone. Ravaud [14] reported significant improvement in functional status evaluated by Lequesne index at weeks 1 and 4 but not beyond. Furthermore, they reported a better functional status in IA lavage group compared to IA cortivazol. Gaffney et al. [12] showed significant improvement in health status assessed by HAQ at weeks 1 and 6 compared to placebo. Despite these contradictory results, a recent Cochrane Database review declared lack of evidence 
concerning the effect of corticosteroids on functional parameters [16]. This study demonstrated significant improvement in parameters related to both quality of life and functional status. Our results represented progress in functional status together with pain relief and improved emotional status and social isolation in parallel.

Our study had several limitations. First, our study group is relatively small and, therefore, our results need to be validated by further studies with larger series including early stages of knee osteoarthritis. Secondly, a blinded IA injection control group is absent in our study. However blinded IA corticosteroid injection in osteoarthritis is an extensively studied technique in literature. Therefore, we did not compose a blinded injection control group. On the other hand, addition of the control group would provide a comparison of guided and blinded injection techniques. Thirdly our followup duration is 4 weeks. Further studies with longer follow-up are needed to document longterm effect of USG guided knee injections.

In conclusion, our study demonstrated a significant analgesic effect of USG guided IA injection at 4 weeks of follow-up. In addition, significant improvement in physical examination findings, functional status and quality of life was obtained. USG guidance may improve the known beneficial effects of corticosteroids in advanced knee osteoarthritis.

Conflict of interest: Authors declare that they have no conflict of interest.

\section{References}

1. Sosdian L, Dobson F, Wrigley TV, et al. Longitudinal changes in knee kinematics and moments following knee arthroplasty: A systematic review. Knee 2014;21:9941008.

2. Cheng OT, Souzdalnitski D, Vrooman B, Cheng J. Evidence-based knee injections for the management of arthritis. Pain Med 2012;13:740-753.

3. Hochberg MC, Altman RD, April KT, et al. American College of Rheumatology 2012 recommendations for the use of nonpharmacologic and pharmacologic therapies in osteoarthritis of the hand, hip, and knee. Arthritis Care Res (Hoboken).2012;64:465-474.

4.Goldwin M, Dawes M. Intra-articular steroid injections for painful knees. Systematic review with meta-analysis. Can Fam Physician 2004;50:241-248.

5. Arroll B, Goodyear-Smith F. Corticosteroid injections for osteoarthritis of the knee: meta-analysis. BMJ 2004;328:869
6. Maricar N, Parkes MJ, Callaghan MJ, Felson DT, O'Neill TW. Where and how to inject the knee-a systematic review. Semin Arthritis Rheum 2013;43:195-203.

7. Tüzün EH, Eker L, Aytar A, Daşkapan A, Bayramoğlu M. Acceptability, reliability, validity and responsiveness of the Turkish version of WOMAC osteoarthritis index.

Osteoarthritis Cartilage 2005;13:28-33

8. The European group for quality of life assessment and health measurement: European guide to the Nottingham Health Profile. Brookwood: Brookwood-Surrey

Medical Publications,1993;1-16.

9. Küçükdevecı $A A$, McKenna $S$, Kutlay $S$, Gürsel $Y$, Whalley D, Arasıl T. The development and psychometric assessment of the Turkish version of the Nottingham

Health Profile. Int J Rehabil Res 2000;23:31-38.

10. Peng PW, Shankar H. Ultrasound-guided interventional procedures in pain medicine: a review of anatomy, sonoanatomy, and procedures. Part V: knee joint. Reg Anesth Pain Med 2014;39:368-380.

11. Marsland D, Mumith A, Barlow IW. Systematic review: the safety of intra-articular corticosteroid injection prior to total knee arthroplasty. Knee 2014;21:6-11.

12. Gaffney K, Ledingham J, Perry JD. Intra-articular triamcinolone hexacetonide in knee osteoarthritis: factors influencing the clinical response. Ann Rheum Dis 1995;54:379-381.

13. Dieppe PA, Sathapatayavongs B, Jones HE, Bacon PA, Ring EF. Intra-articular steroids in osteoarthritis. Rheumatol Rehabil 1980;19:212-217.

14. Ravaud P, Moulinier L, Giraudeau B, et al. Effects of joint lavage and steroid injection in patients with osteoarthritis of the knee: results of a multicenter, randomized, controlled trial. Arthritis Rheum 1999;42:475-482.

15. Jones A, Doherty M. Intra-articular corticosteroids are effective in osteoarthritis, but there are no clinical predictors of response. Ann Rheum Dis 1996;55:829832.

16. Bellamy N, Campbell J, Robinson V, Gee T, Bourne R, Wells G. Intraarticular corticosteroid for treatment of osteoarthritis of the knee. Cochrane Database Syst Rev 2006;2:CD005328. 